\title{
The COETF Annual Awards Program for 2012
}

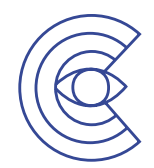

The Canadian Optometric Education Fund (COETF) received a total 37 applications for awards in 2012. Of those 37 applications, 25 were granted at least partial funding for projects or research. In most cases, applicants are not given full funding as the total amount of funding requested greatly exceeds the money available for granting. Awards funding is based on the Trust Fund's interest earned over the previous year.

All award recipients are required to submit an interim report on their project and a final report upon completion. In an effort to recognize some of the projects and research being done by COETF award recipients the Awards Committee will publish project reports in the Canadian Journal of Optometry (CJO) so that our members across the country can learn more about where COETF funding goes, as well as highlighting exciting optometric research.

\section{The COETF Annual Awards Program for 2012}

SCHOOL OF OPTOMETRY AND VISION SCIENCE, UNIVERSITY OF WATERLOO Stacey Chong (Master's Degree Program) "Can retinal ganglion cells regenerate?"

\section{QUICK FACTS}

The COETF was created in 1976 by the members of the Canadian Association of Optometrists to assist programs in research, education and human resources development in the vision and eye care field in Canada.

Through its annual program of Awards, the COETF has supported faculty development, research and/ or specialized education programs carried out by graduate students and investigative projects conducted by undergraduates and faculty at Canada's schools of optometry, as well as projects undertaken by independent practitioners or members of the public.
Brad Hall (PhD Program) "Investigation of short term lactoferrin conformation on contact lenses using raman spectroscopy"

Amith Hathibelagal (Master's Degree Program) "A novel objective measure of infant visual acuity using gaze tracking"

Charlene Hickey (Optometry student project) "Tracking the development of binocular vision following spectacle correction in young children"

Alex Hui (PhD Program) "The effect of release solution replenishment on ciprofloxacin drug release from model silicone"

Salsabeel Jadi (Master's Degree Program) "The efficiency of multi-purpose solutions in removing protein from silicone hydrogel contact lens materials"

Varadharajan Jayakumar (Master's Degree Program) "Effect of source characteristics of an illuminated Placido disc on measurement of anterior surface aberrations"

Holly Lorentz (Post-Doc Program)

"The efficacy of newer multipurpose cleaning solutions on lipid removal from silicone hydrogel contact lenses"

Nicholas Lorentz (PhD Program) "Investigation in vergence adaptation"

Museum Of Visual Science "Historical Archive/Museum Exhibit"
Alan Ng (Master's Degree Program) "Development of a novel fluorescent based lysozyme assay to study the conformational state of lysozyme deposited on contact lenses"

William Ngo (Master's Degree Program) "Imaging meibomian glands with OCT"

Heinz Otchere (Master's Degree Program) "Fitting semi-scleral lenses using corneal sagittal depth measurement and assessment of visual acuity"

Chau-Minh Phan (PhD Program) "Antifungal natamycin uptake and release in commercial contact lenses"

Marc Schulze "Determining the ocular shape in children and adults using optical coherence"

Thanh Tran (Master's Degree) "Characterization of retinal degeneration in Smoky Joe chickens"

Chitman Uppal (Master's Degree Program) "Relative choroidal and retinal vascular reactivity in diabetic retinopathy"

Jalaiah Varikooty (PhD Program) "Estimating in-vivo contact lens wettability through tear film hydrodynamics"

Hendrik Walther (Master's Degree Program) "Conformational state of meibum lipids in solution using raman spectroscopy"

Gah-Jone Won (Master's Degree Program) "The effects of non-muscle inhibitors on the biomechanics of the avian crystalline lens"

\begin{tabular}{l|l|l}
\hline Total Waterloo School of Optometry Applications & 29 & $\$ 164,650.98$ \\
\hline Total Waterloo School of Optometry Awards & 21 & $\$ 38,000.00$ \\
\hline Total Montréal École d'Optométrie Applications & 6 & $\$ 25,500.00$ \\
\hline Total Montréal École d'Optométrie Awards & 3 & $\$ 8,500.00$ \\
\hline Total Independent Practitioner Applications & 2 & $\$ 6,445.00$ \\
\hline Total Independent Practitioner Awards & 1 & $\$ 1,000.00$ \\
\hline Total Applications for 2012 & 37 & $\$ 196,595.98$ \\
\hline Total Awards for 2012 & 25 & $\$ 47,500.00$ \\
\hline Total Applications (since inception) & & $\$ 6,417,867.76$ \\
\hline Total Awards & & $\$ 1,821,013.00$
\end{tabular}


Witer Learning Resource Centre " Continuance of 'Library Information Resources \& Services for Canadian Optometrists' program"

\section{ÉCOLED'OPTOMÉTRIE,} UNIVERSITÉ DE MONTRÉAL

Estefania Chriqui (Master's Degree Program) "Optimizing the determination of visual acuity in seniors who have considerable difficulties communicating or co-operating during the visual exam."

Hélène Kergoat, Elizabeth Irving "Convergence insufficiency and Parkinson's disease"

\section{Yves Momplaisir, Maxime Gosselin}

"Canadian optometrists' contribution to the management of eye disease"

\section{INDEPENDENT PRACTITIONER}

\section{Alissa Boroditsky "Oral History of}

Optometry in Canada"

\section{COEFT REPORTS}

In an effort to highlight some of the projects and research by COETF award recipients, the COETF Trustees and Awards Committee have selected project reports to be published in the Canadian Journal of Optometry (CJO). Recognizing that many recipients intend to publish their work in cited journals, the reports are not considered to be clinical articles. COETF funded research, when completed and peerreviewed may be published in the $\mathrm{CJO}$ and other journals. The COETF reports are intended to provide relevant information for the benefit of our readers and to showcase the high calibre of optometric research funded by COETF, Canadian optometry's charity.

Research and academic support are vital to our profession. COETF is our charity and needs our contributions, now more than ever. Please give generously and often. To donate online or download a donation form, visit: opto.ca/coetf

Lien français : opto.ca/ffoce

COETF REPORT 2012

\section{Manitoba Association of Optometrists Museum Project}
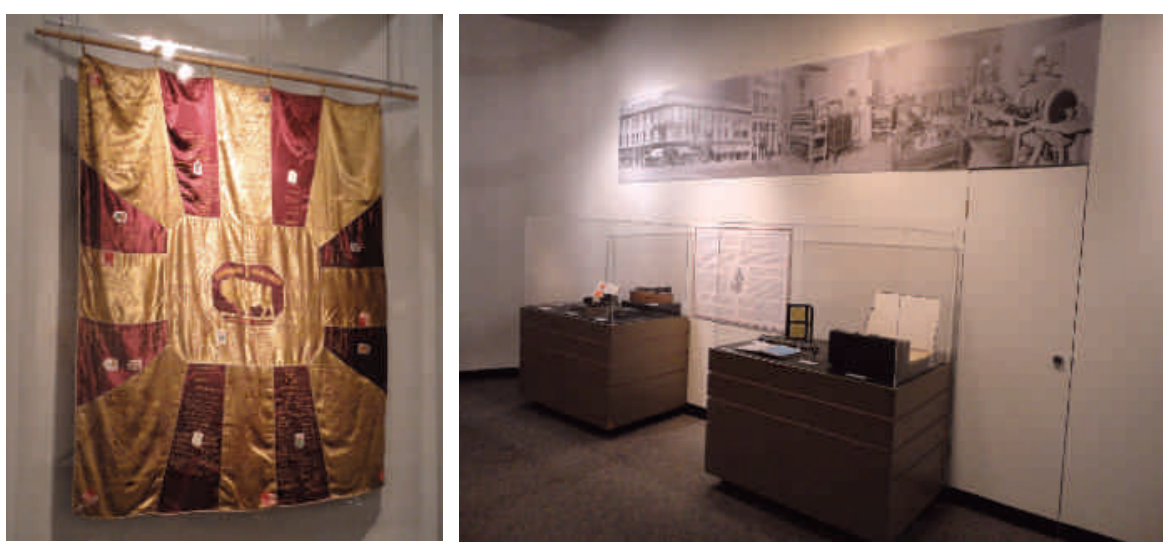

By Cheryl Bayer BSc, OD,

MAO Museum Committee Chair

In 2011, the Canadian Optometric Education Trust Fund (COETF), the Manitoba Association of Optometrists (MAO) Museum Committee, the Canadian Association of Optometrists (CAO) financially contributed to MAO's Looking Back: A Century of Vision Science display that was exhibited at the Manitoba Museum and including during the CAO Congress in Winnipeg.

The project primarily focussed on the history of optometry within the past century; however, some aspects of optics as well as the origins and designs of spectacle and contact lenses were also covered. The display opened at the Manitoba Museum on June 23, 2011 and was available for public viewing until September 5, 2011. The MAO hosted a private unveiling of the display exclusively for MAO members on June 27, 2011.

As projected, the vast majority of the artefacts displayed were borrowed from MAO members. A few artefacts, including but not limited to an old slit-lamp, prosthetic eyes and sample and model IOL's, were graciously loaned to the project by industry partners and colleagues from other specialties within the eye-care field. One of the highlights of the display was the quilt, embroidered with names of COETF donors, from a previous CAO congress in Winnipeg. The quilt provided a veritable who's who of the profession at the time.

The display itself consisted of seven covered display cases, a mock exam lane, informational poster boards (Optometry Myths, A Brief History of Optometry, The Exam Lane and The COETF Quilt). There were also two black and white poster boards displaying the interior of an optical lab circa 1920 and the outside of an optometrist's office in downtown Winnipeg. A static-mounted wall decal had the name and an explanation of how the display came into existence.

Unfortunately The Manitoba Museum does not have data available regarding the number of visitors who would have seen the display; however, they did receive a lot of positive feedback regarding its educational and aesthetic appeal. The official curators from the museum were very impressed that a group of optometrists, with the assistance of our designer, could put together such an appealing and informative exhibit! They assured me that the summer months are the busiest and that our display was ideally located for patrons to see on their way out.

The Looking Back display was also featured during Museum Bingo, an event which took place during the CAO Congress' Opening Ceremonies.

The funding provided by COETF was matched by the CAO and the additional funds required for the project were supplied by the MAO. Completion of this project on budget was possible thanks to the many long hours of volunteer work done by the MAO Museum Committee members and staff of the MAO. 